Zagadnienia Rodzajów Literackich, LX, z. 3

PL ISSN 0084-4446

DOI: $10.26485 / Z R L / 2017 / 60.3 / 12$

Dorota UTRACKA

Akademia Humanistyczno-Ekonomiczna w Lodzi*

\title{
Humanistyczne aspekty architektury informacji. Rekonesans
}

\author{
Humanistic Aspects of Information Architecture. Reconnaissance
}

\begin{abstract}
The article presents the essence of information architecture as a process of nomenclature organization, navigation design and the search systems useful in information management. The key issue is to show in what way art and science of information environments management are becoming the tool for humanizing technology and the instrument of social development, as well as the way information architecture is becoming an inseparable part of humanistic, meta-scientific and practical aspects of the 21 st century informatology. The authoress discusses various aspects of culture in Web 2.0 model, the main attributes of text architecture and also its inter-media communication functionality, scrutinizing the relation between culture of the surplus and the Internet axiology, the assumptions of economics and knowledge ecology as well as information engineering.
\end{abstract}


* Katedra Literaturoznawstwa Akademii Humanistyczno-Ekonomicznej ul. Sterlinga 26, 90-212 Łódź

e-mail: d.utracka@gazeta.pl 
Tam, gdzie jest informacja, jest takiže architektura.

(Jesse J. Garret)

Nadajac ksztatt budynkom, ksztattujemy siebie.

(Winston Churchill)

Postawiony w tytule problem zakłada kwestię dialogowego paradygmatu nauk i dyscyplin, w obrębie którego żywotnym pozostaje pytanie o możliwości, obszary oraz praktyczne formy tego dialogu. Interesować nas będzie zatem dwustronność, wymiana, komplementarność, dążenie do sytuacji, kiedy dialogiczność staje się źródłem generowania jakości transdyscyplinowych, czyli takich, które, wychodząc niejako ponad własne zakresy i obszary, tworzą coś w rodzaju nadwyżki, wartości dodatkowej. W tym kontekście kluczowymi pozostaja pytania: czy humanistyka stanowi dobro samo w sobie, czy raczej zostaje dowartościowana poprzez możliwości wykorzystania jej przez narzędzia technologiczne? $\mathrm{Na}$ ile mało ekspansywny dyskurs humanistyki może wpływać na charakter i przebieg procesów technologizacji kultury i informatyzacji społeczeństwa? Czy i w jaki sposób humanistyka jest potrzebna technologiom? Czy muszą one determinować jej charakter i perspektywy rozwoju, czy też możliwy jest proces odwrotny? W jakim stopniu zatem humanistyka cyfrowa jest humanistyczna? Czym charakteryzuje się aksjosfera cywilizacji technicznej i wreszcie: na czym polega humanistyczny potencjał elektronicznej antroposfery oraz edukacyjna i prohumanistyczna wartość języka techniki?

Choć poniższe rozważania moga być jedynie przyczynkiem do szerszej dyskusji, prowadzonej przecież od dawna, to, dla właściwego zrozumienia intencji ukrytej w temacie niniejszego artykułu, istotne wydaje się na wstępie ustalenie choćby ogólnego sensu słowa humanistyka. Abstrahując od kulturowej tradycji pojęcia i znakomitych skądinąd rozpraw poświęconych próbom zdefiniowania humanistyki, na potrzeby naszych rozważań przyjmiemy pewną dwupoziomowość znaczeń.

Pierwszy poziom znaczenia odsyłał nas będzie do humanistyki jako zespołu nauk i dyscyplin, których przedmiotem badań jest człowiek jako istota społeczna i jego twórczość. Skłonni będziemy przy tym opowiadać się za modelem „humanistyki otwartej”, swoiście 
wielodyscyplinowej, heteronomicznej — rozumiejącej, kognitywnej, obiektywnie „relatywistycznej”, u podstaw której leży tzw. pluralizm metodologiczno-teoriopoznawczy. Pozostajemy jednak świadomi tego, że problem integracji badań humanistycznych łączy się nieodmiennie z jednością przedmiotową i/lub spójnością metod badawczych (Zamiara 2002). Stąd istotnym aspektem będą także rozstrzygnięcia pojęciowe proponowane przez Jerzego Kmitę, w jego projekcie „humanistyki zintegrowanej”, stanowiącej — zdaniem filozofa — teren rozpoznawania ,konkretnych zjawisk lub procesów zachodzących (...) na obszarze wybranych dziedzin kultury w konfrontacji ze zjawiskami czy procesami z równoległych (między in. chronologicznie) dziedzin kulturowych. W grę wchodziłyby również mniej lub bardziej pod względem swego zakresu rozciagnięta teoria kultury” (Kmita 2002). Objaśniając teoriopoznawcza i metodologiczną podstawę „humanistyki zintegrowanej”, Mateusz Bonecki określa ją jako „ogół dyscyplin naukowych, które łączy to, że posługują się one metoda interpretacji humanistycznej polegającej na wyjaśnianiu ludzkich czynności oraz ich wytworów poprzez przypisywanie przekonań kulturowych podmiotom tych czynności” (Bonecki 2012: 53). Oznacza to przyjęcie normatywno-dyrektywnego pojęcia kultura, której interpretacja wymaga racjonalizacji przekonań zastosowanych w opisie i rekonstrukcji kultury. „Tym samym — jak powiada autor — przedmiotem zainteresowań bumanistyki zintegrowanej stają się systemy przekonań organizujące przestrzeń kooperacji, tj. zawierające praktyczne instrukcje dla działań oraz reguły ich kulturowej interpretacji” (Bonecki 2012: 53).

Zwieńczeniem nowoczesnej teorii humanistyki jest teza o jej związku ze światem wartości. Stąd w proponowanych tu rozważaniach komplementarnym wobec pierwszego staje się drugi poziom znaczeń, w którym eksponować chcemy rolę łacińskiego rodowodu słowa 'humanistyczny’ (łac. bumanus — ludzki), skupiając naszą uwagę na sferze trwałych i uniwersalnych wartości, a także idei, postaw i kompetencji służących rozwojowi duchowo-egzystencjalnej kondycji człowieka w świecie dóbr kulturowych, ale także człowieka jako podmiotu i kreatora zmian kulturowych.

Kluczową kategorią będzie dla nas, rzecz jasna, pojęcie bumanistyki cyfrowej zajmującej się człowiekiem i jego wytworami w przestrzeni wirtualnej; wykorzystującej narzędzia i metody oparte na technologiach informatycznych oraz badajaccej jak tradycyjne działy nauk humanistycznych realizują się w rzeczywistości wirtualnej (Bomba 2013).

W tej perspektywie za cel naszych rozważań uznajemy próbę odpowiedzi na pytania: czym zajmuje się architektura informacji, na czym polega jej interdyscyplinarny status pragmatyczny i metanaukowy (aspekt naukoznawczy/naukometryczny i humanistyczny)? Jakie jest miejsce architektury informacji w obszarze takich nauk, jak informatologia i komunikologia? Czy i w jaki sposób kultura nowych technologii poszerza granice nowego paradygmatu humanistyki?

\section{Kultura nadmiaru. W stronę ekologii i ekonomii informacji}

Zgodzić należy się z przekonaniem głoszącym, iż „świat, w którym tak istotne są nowe technologie, pozwalające na niespotykaną skalę globalnego przepływu: ludzi, towarów, informacji, jest światem, w którym sieciowa struktura wypiera tradycyjne grupowe konfiguracje" (Jonak, Mazurek i Tarkowski 2006: 9). Nieustanny przepływ zmultiplikowanych i często niepełnych czy też zniekształconych danych włącza bez mała wszystkich uczestników „kultury konwergencji” (Jenkins 2008) w mediologiczny spektakl, a za nim w wyścig o palmę pierwszeństwa w dostępie do informacji. O charakterze i obiegu informacji 
współdecydować może każdy. „Demokracja Sieci”, tak samo jak demokracja w ogóle, narzuca zobowiązania i staje się w gruncie rzeczy niełatwym obszarem masowej aktywności. Człowiek doby Internetu, włączony w galopujący proces gigantycznej redundancji informacyjnej, niezdolny jest samodzielnie dokonywać selekcji. Powszechna progresywność Sieci jako systemu referencyjnego sprawia, że odbiorca informacji sieciowej jest z konieczności mieszkańcem krainy chaosu, uwikłanym w hipertekstualny paradygmat świata linków, mnożących się kodów i znaczeń. Bezwład nadmiaru, o którym tak sugestywnie pisał Jean Baudrillard, sprawia, że niezbędny staje się klucz do labiryntu, znajomość ,gramatyki”, dzięki której wielogłos sieci nie staje się matnią, ale dobroczynnym oceanem dóbr (Krzysztofek 2010: 66).

Problemy związane z jakością, organizacją i odbiorem informacji zrodziły potrzebę stworzenia standardów integrujących dziedziny wiedzy, stworzenia narzędzi projektowania, udostępniania i zarządzania informacja. Próbą regulacji nadmiaru informacji stają się aktywne już od początku funkcjonowania Internetu mechanizmy selekcjonowania, kategoryzacji czy agregacji publikowanych treści. Konsekwencja popularyzacji stron WWW było, jak wiemy, powstawanie katalogów stron i prywatnych zestawów linków oraz dynamiczne rozwijanie się wyszukiwarek, które zaczęły ogarniać wszystko, co poddało się indeksowaniu. Jak słusznie zauważa Jim Gray, „większość danych w Sieci ma postać niestrukturalnego tekstu", co stwarza konieczność przetwarzania danych na model semistrukturalny, tworzenia sieciowych baz danych i relacji między nimi. W procesie strukturalizacji jako tworzeniu cyfrowego metajęzyka „wszystko jest dokumentem, wszystko jest obiektem, wszystko jest relacją" (Gray 2001: 7).

Odpowiedzią na ten stan rzeczy staje się od kilku dekad dynamicznie rozwijająca się, interdyscyplinarna nauka, czy — jak chcą niektórzy — sztuka, zwana ,architekturą informacji”. Terminu użył po raz pierwszy Richard Saul Wurman w 1976 roku. Początkowo 'architekturą informacji' określano praktyczne umiejętności związane z tworzeniem komunikatów informacyjnych, ale z czasem rozwoju i popularyzacji hipertekstowej usługi WWW, metody przez nią stosowane zaadaptowano do budowy serwisów internetowych (Skórka 2002).

Louis Rosenfeld i Peter Morville w swej obszernej pracy Architektura informacji w serwisach internetowych wyprowadzają definicje pojęcia ,architektura informacji” z błyskotliwie przeprowadzonych analogii między swoiście rozumianą filozofia projektowania budowli architektonicznych (od średniowiecznych katedr po stalowo-szklane konstrukcje wieżowców, sześciany biur i mieszkań; od efektownych przestrzeni ogrodów po wnętrza zacisznych kawiarni) a zasadami projektowania i tworzenia konstrukcji w krajobrazie wirtualnym. Efektem tych porównań jest celna skądinąd konstatacja:

Sukcesem budowniczych są tylko te budowle, w których całość oddziałuje na nas silniej niż poszczególne części składowe. (...) Tak jak budynki, serwisy WWW mają swoją architekturę, która wzbudza nasze określone reakcje. [Źle zaprojektowane serwisy] przypominają nieudane budynki: domy z płaskimi przeciekającymi dachami, kuchnie, w których brak miejsca na przyzwoita szafkę-stół do przyrządzania potraw, biurowe wieżowce, w których nie można otwierać okien i labirynty nie dość dobrze oznaczonych portów lotniczych. (Rosenfeld i Morville 2003:19-20)

To właśnie oddaje istotę zależności, która zdaje się wyjaśniać, czemu służy i jakie zadania stawia sobie architektura informacji. Zdefiniować ją możemy zatem jako: 
- nową dyscyplinę poznawczą i praktyczną zajmującą się dostarczaniem zasad projektowania i tworzenia konstrukcji w krajobrazie wirtualnym;

- sztukę oraz naukę nadawania struktur i klasyfikowania serwisów (stron) internetowych $\mathrm{i}$ intranetowych, mających na celu ułatwienie ludziom znajdywanie informacji i ich wykorzystywanie;

- $\quad$ strukturalne projektowanie przestrzeni informacyjnej, służące ułatwieniu kompletowania informacji i udostępnianiu ich użytkownikom;

- proces organizowania nazewnictwa, projektowania nawigacji i systemów wyszukiwawczych pomocnych w znajdywaniu i zarządzaniu informacja,

- kombinację systemów: organizacji, nazewnictwa, wyszukiwania i nawigowania w przestrzeniach informacji (Rosenfeld i Morville 2003: 20).

Rosenfeld i Morville wyróżnili cztery podstawowe składniki architektury informacji jako systemów hipertekstowych w Internecie. Należą do nich systemy: organizacji, oznaczeń, nawigacji oraz system wyszukiwania. System organizacji jest systemem grupowania treści, system oznaczeń ustala nazwy dla wydzielonych grup treści, nawigacja jest systemem umożliwiającym poruszanie się po serwisie i przeglądania jego zawartości, zaś system wyszukiwania pozwala na formułowanie zapytań, które porównywane są z dokumentami relewantnymi (Rosenfeld i Morville, cyt. za: Skórka 2002). Architekt informacji — zdaniem Richarda Saula Wurmana — to osoba, która tworząc strukturę lub mapę informacji, pozwala innym znaleźć własną ścieżkę do wiedzy. Co więcej, jest to ktoś, kto wypracowuje wzorce właściwe dla kształtu i obiegu informacji, konstruując systemy, które będą wyznaczać standardy komunikacji XXI wieku (Skórka 2002).

Można zapytać, czy architektura informacji jest i czy może być nauką? Czy jest zaledwie dziedziną wiedzy? Czy potrafi tworzyć interakcje śróddyscyplinowe? Warto podkreślić, że z terminem ,architektura informacji” początkowo kojarzono wyszukiwanie metod i procedur projektowania przestrzeni informacyjnej, a samo pojęcie funkcjonuje wciąż jako praktyczna umiejętność zawodowa. Dyskusje w gronie praktyków i zwolenników stworzenia naukowych podstaw architektury informacji pozwoliły doprowadzić do reorganizacji dotychczasowych metod od lat obecnych w rozwoju technologii informacyjnych, nadając nowy kierunek zasadom tworzenia środowisk informacyjnych (Skórka 2016: 555-576).

Wychodząc naprzeciw tej tendencji, można przyjąć nieco szerszą perspektywę; uznać architekturę informacji za kompleksową i wielodziedzinową naukę pozwalającą wyjaśniać naturę przestrzeni informacyjnej, gdzie przez informację rozumieć będziemy „relacyjne bazy danych (...) wszelkiego kształtu i rozmiarów serwisy internetowe, dokumenty, programy-aplikacje, obrazy i inne, łącznie z tzw. metadanymi, czyli atrybutami i danymi o zawartości oryginalnych obiektów, takich jak dokumenty, ludzie, procesy i organizacje" (Rosenfeld i Morville 2003: 21). W obszarze jej zainteresowań i meatanukowych kontekstów pozostaną zarówno tradycyjna teoria wyszukiwania, zorientowana na systemy (system-oriented) - Information Retrieval, jak i humanistyczna koncepcja poszukiwania informacji i zachowań informacyjnych (buman-oriented) - Information Seeking, Information Behavior, Human Information Behavior. Problematyka dotycząca kultury informacyjnej (Information Literacy) nie pozostaje poza kwestiami pragmatyki organizacji, zarządzania informacja i wiedza (Information Management, Knowledge Management, Knowledge Organization; 
Cisek 2008). Użytecznym wsparciem dla omawianej dyscypliny okażą się dziś z pewnością nie tylko metodologie badań internetowych, semiotyka i antropologia nowych mediów, ale kategorie i instrumentarium badawcze teorii reklamy, ekologii mediów, teorii zarządzania, a także, sprzymierzone z pragmatyką mediologiczna, metody badań marketingowych. Możemy zatem na prawach partnerskiego dialogu umieścić architekturę informacji w kręgu takich dyscypliny, poddyscyplin, czy też dziedzin wiedzy, jak: psychologia poznawcza, ergonomia, ekologia informacji, ekonomia wiedzy, inżynieria użyteczności, bibliologia cyfrowa i współczesna informacja naukowa, informetria, bibliometria, webometria, naukometria, socjologia, antropologia i semiotyka mediów, cyberkultura, socjo-, psycho- i etnolingwistyka, cyberlingwistyka, projektowanie graficzne i wizualne, typografia, muzealnictwo i wystawiennictwo, zarządzanie wiedza, komunikacja marketingowa, infobrokering, projektowanie komunikacji i interakcji czy wreszcie szeroko rozumiana informatyka i wiedza o socjokulturowych mechanizmach przestrzeni Internetu.

Przywołana wielokontekstowość pokazuje, że architektura informacji nie jest li tylko dziedziną o proweniencji informatyczno-technologicznej. Potraktować ją należy bowiem jako dyscyplinę, czy może lepiej metadyscyplinę, której celem jest synergia wielu dyscyplin humanistycznych i pozahumanistycznych czy parahumanistycznych. Byłaby ona zatem terenem kształtowania się nowego języka „humanistyki otwartej”, w pełni wykorzystującej zarówno metodologiczno-pojęciowe zaplecze innych nauk, jak i narzędzia rzeczywistości wirtualno-technicznej kształtowane przez nowoczesne technologie komputerowe - wykreowane przecież przez czynnik jak najbardziej humanistyczny, czyli ludzki intelekt. Architektura informacji, „pracując” na rzecz nowego paradygmatu humanistyki, byłaby zatem subdyscypliną nauki o komunikacji w jej rozumieniu medioznawczym, eksponującym aspekty technologiczne czy wręcz matematyczno-cybernetyczne, służąc niejako translacji treści technologicznych i informatycznych na treści humanistyczne, ale i odwrotnie wprowadzałaby w obszar nowych technologii zagadnienia wpisane w kanon tradycyjnie i nietradycyjnie rozumianej humanistyki. W jej obszarze mieści się bowiem wielodyscyplinowy, lub inaczej mówiąc, „nieparadygmatyczny model nauki o komunikacji” (Kulczycki 2011: 50-51). Uznając jej mobilny status, pozostajemy zgodni co do faktu, że jej nurt cybernetyczno-informatyczny, traktowany jako fundament transmisyjnego ujęcia komunikacji w ujęciu Claude'a Shannona i Warrena Weavera, pozostaje najbliższy poznawczym i praktycznym zadaniom dzisiejszej architektury informacji. W krytycznej refleksji nad funkcja i znaczeniem cybernetycznego modelu komunikacji Michał Wendland proponuje definicje mieszczące się w paradygmacie transmisyjnym, zgodnie z którymi komunikacja to m.in. transmitowanie bodźców werbalnych w celu ,zmodyfikowania zachowania innej jednostki, transmisja informacji, idei, emocji, umiejętności itp. za pośrednictwem symboli — słów, obrazów, figur, grafów" (Wendland 2014: 53).

Śledząc aktualne badania z zakresu filozofii komunikacji, można jednak zauważyć przeniesienie punktu ciężkości z „technologii” na „kulturę” oraz mediologię filozoficzną i antropologiczno-kulturową w ujęciu, jakie proponował między innymi Velém Flusser czy Marshall McLuhan. Takim tendencjom rozwojowym zaświadczają zarówno praktyki badawcze wzbogacania dyskursu skupionego wokół antropologii Sieci o aspekty filozoficzno-społeczne, jak i zwrot rytualno-kulturologiczno-etnograficzny w komunikologii (zob. Wendland 2014: 9-20, 56-59). Można zatem spodziewać się, że z czasem tzw. transmisyjne ujęcie modelu komunikacji nie będzie pozostawać w opozycji do ujęcia kulturalistycznego. 
Pozwoliłoby to spojrzeć na architekturę informacji, po pierwsze jako na dyscyplinę z pogranicza nauk społecznych i humanistycznych, po drugie, zobaczyć w niej komponent multidyscyplinowości, jaka wpisuje się w, proponowany przez Richarda L. Lanigana, naukowy paradygmat komunikologii jako dyscypliny humanistycznej, która

(...) posługuje się metodami semiotyki oraz fenomenologii do wyjaśniania ludzkiej świadomości oraz zachowań w obrębie kultury. Jej subdyscypliny to: (1) komunikologia medialna (Media Communicology) — antropologiczne, psychologiczne oraz socjologiczne analizy ludzkiego zachowania w kontekście mediów elektronicznych, fotografii oraz telekomunikacji. (2) komunikologia kliniczna (Clinical Communicology) — nastawienia terapeutyczne na a) zaburzenia komunikacyjne związane z zaburzeniami mowy oraz słuchu lub b) pomyłki w zachowaniu spowodowane mylną informacja (na poziomie pragmatycznym lub semantycznym). (3) komunikologia sztuki (Art Communicology) — studia nad estetyką mediów jako kulturowej transmisji oraz rozprzestrzeniania się, w szczególności jako performatywnej twórczości, np. taniec, opowiadania ludowe, muzyka, ikonografia oraz malarstwo. (4) filozofia komunikologii (Philosophy of Communicology) — studia nad komunikacją w szeroki kontekście służące wyjaśnianiu języka, lingwistyki, kognitywistyki oraz cybernetyki wewnątrz dyscyplin filozoficznych: metafizyki, epistemologii, logiki oraz estetyki. (Lanigan, cyt. za: Wendland 2014: 23)

Z perspektywy zaplecza metodologicznego architektura informacji bazuje w zasadniczym stopniu na podstawach wypracowanych przez informatologię, która, zdaniem Sabiny Cisek ,integruje to, co fizyczne, materialne (nośniki, technologia), psychiczne (użytkownicy informacji) oraz idealne (informacja jako globalny kapitał ludzkiej wiedzy). Laczy indywidualne ze społecznym, subiektywne z obiektywnym" (Cisek 2008). Takie generalizowanie funkcjonalności metodologicznej staje się jednak źródłem pewnych ograniczeń, prowokując uzasadnione watpliwości, na przykład — czy można za pomocą tych samych strategii i metod badać ludzkie stany psychiczne (np. potrzeby informacyjne) i techniczne aspekty systemów informacyjno-wyszukiwawczych? Cisek wskazuje, iż pewne próby rozwiązań metodologicznych aporii przynosiły badania skupione na filozoficznych uwarunkowaniach pojęć i obszarów nauki o informacji, takich jak: dane, etyka informacji, informacja w ogóle, jakość informacji, ontologie, reprezentacja wiedzy, teoria wyszukiwania, wiedza, wywiad gospodarczy (competitive intelligence), zarządzanie informacją (Cisek 2002: 19-25, 118 i nast.). Znawczyni metanaukowych parametrów informatologii przywołuje, cenne z punktu widzenia prowadzonych tu rozważań, obserwacje Fredricka Astroma, który wskazał na dwa stabilne obszary badań współczesnych nauk o informacji: (1) wyszukiwanie/poszukiwanie informacji (Information Retrieval/Information Seeking) oraz (2) informetria/ webometria. Astrom podkreśla przy tym, że zmiany w obrębie wspomnianych obszarów idą w kierunku humanistycznej koncepcji poszukiwania informacji, koncentracji na użytkowniku, jego potrzebach i preferencjach poznawczych. Co więcej, jak zauważa Cisek, da się wyróżnić integrację obu obszarów oraz wyraźną tendencję dominacji badań webometrycznych nad klasyczną informetrią. Sama zaś nauka o informacji, jako „naddyscyplina” architektury informacji, w swej ekspansji badawczej zdaje się wciąż poszerzać, czy może dookreślać jej zakres poprzez badania obejmujące: pojęcie informacji, profile użytkowników informacji i analizę ich zachowań, teorie oraz techniki wyszukiwania i relewancji danych, funkcjonalność nowych metod bibliometrii, webometrii i naukometrii. Proces ten wpisuje się w projekty metanaukowe o charakterze mediacyjnym, zaświadczając aktualizacji badawczych podejść „,ze współczynnikiem humanistycznym” (Cisek 
2002: 12-13). Można rzec zatem, że odejście od cybernetyczno-technologicznego modelu informatologii, związanego z systemami, usługami i produktami, wiąże się coraz częściej z potrzeba pogłębienia refleksji naukowej o aspekty humanistyczno-społeczne, w tym te, które służą rzeczywistemu upowszechnianiu osiąnięć i dóbr kultury z jej ewolucją i wciąż zmieniającym się językiem sztuki. Samo pytanie o podmiotowy status odbiorcy, badacza i współtwórcy kultury Sieci i kultury w Sieci wydaje się otwierać wciąż nowe obszary dla poszerzenia paradygmatu nauki o informacji (zob. Babik 2016: 61-88).

\section{Humanista digitalny, czyli wokół modelu kultury Web 2.0}

Galaktyka Internetu, generując nowe narzędzia, od kilku lat przyczynia się do upowszechniania modelu kultury Web 2.0, widocznej w nowym języku nauki, biznesu, mediów, obiegów kultury, jej zarządzania i popularyzacji. Same zaś badania odsyłające do konkretnych dziedzin i obszarów życia przyczyniły się do upowszechnienia takich pojęć jak: Biznes 2.0, Nauka 2.0, Kultura 2.0, Humanistyka 2.0. Faktem jest, że „społeczny wymiar Internetu Drugiej Generacji odnosi się do specyficznej roli, jaką odgrywa użytkownik Sieci. Internauta stał się bowiem w dobie 2.0 współtwórcą, komentatorem i moderatorem treści zamieszczanych w serwisach internetowych" (Tyszkowska 2015: 9-11). Skutkuje to swoistym uwolnieniem informacji, dialogową relacją między mnożącymi się ekspresjami, językami, przyrostem wiedzy, której strukturalizacja opiera się na społecznościowej „korekcie” i „cenzurze” przydatności (zjawisko tagowania). Kultura cyfrowa to zatem nie tylko subrzeczywistość sieci, ale rodzaj nowego języka, jaki determinuje kształt współczesnej komunikacji społecznej i kulturowej, nowego charakteru tworzyw i modeli obiegu tekstów kultury (zob. Gmiterek 2016: 599-620).

W duchu Web 2.0 toczy się zmiana paradygmatu kultury, czego wyrazistym przejawem jest, trwający od blisko trzech dekad, intensywny proces ewolucji bibliotekoznawstwa i bibliotekarstwa, dostosowującego się do realiów nowoczesnych technik cyfryzacji dóbr kultury pisanej. Bibliolodzy i informatycy konfrontują nieustannie swe stanowiska nie tylko w kwestii definicji pojęcia „digitalizacji w bibliologii” — określania jej zakresów, technik, metod i narzędzi, ale także, a może przede wszystkim w kwestii spójnej strategii zorganizowania systemu udostępniania zbiorów w postaci elektronicznej, a także zarządzania informacją (Pieczonka 2007: 177-180). Stąd niezmiennie aktualizowanymi zagadnieniami współczesnej praktyki bibliologicznej pozostają kwestie otwartych zasobów edukacyjnych, standardów archiwizacji dokumentów elektronicznych, zastosowania technologii mikrokomputerów w bibliotekach, prawno-autorskich aspektów działalności bibliotek i archiwów czy wreszcie projektowania i oceny systemów informacyjno-wyszukiwawczych. Bibliologia cyfrowa oraz badanie zjawiska Biblioteki 2.0 koncentruje zainteresowania znawców przedmiotu wokół kwestii tworzenia zasobów informacyjnych online, w tym - 2.0, zastosowania narzędzi Web $2.0 \mathrm{w}$ dziedzinie zarządzania wiedza, katalogowania 2.0, bibliotecznych forów dyskusyjnych, marketingowego zarządzania biblioteka cyfrowa, blogomanii i blogosfery, rozpoznawania profili użytkowników, tworzenia grup wirtualnych, typologii mediów społecznościowych, czy wreszcie zagadnień skupionych wokół zjawiska folksonomii i serwisów stosujących mechanizm wiki. Cennym uzupełnieniem tychże badań są analizy narzędzi, charakterystycznych dla nurtu Web 2.0, takich jak: kanały RSS, komunikatory internetowe, fora dyskusyjne czy podcasty, a także społeczny katalog biblioteczny (SOPAC) (Tyszkowska 2015: 13-14). 
Znawcy przedmiotu dowodzą, że cyfryzacja dóbr kultury stała się koniecznością cywilizacyjna, odpowiedzią na postępujące procesy „kultury nadmiaru” z wszystkimi jej ekonomicznymi i ekologicznymi konsekwencjami (Grygrowski 2001:170-180). Atutami procesów cyfryzacyjnych stały się: dostępność dokumentów szczególnie chronionych, stały, pozbawiony ograniczeń czasowych dostęp do jednego tekstu nieograniczonej liczby odbiorców oraz — tak ceniona dziś — miniaturyzacja dokumentów (Lesk 1997: 36-38) Tworzenie wirtualnych księgozbiorów w swej istocie opiera się na organizacji przestrzeni danych (książek, map, dokumentów czy zdjęć) i udostępnieniu ich użytkownikom w postaci odpowiednio zaprojektowanych stron WWW, których zawartość, układ przestrzenny i wewnętrzna organizacja nawiązują do klasycznych bibliotek, imitując niejako (zależnie od specyfiki zasobów) przestrzenną strukturę archiwów, czytelni, muzeów, galerii czy też salonów wystawowych.

Przestrzeń Sieci z całym swym zapleczem technologicznym, ale i społeczno-komunikacyjnym sprawia, że współczesna kultura książki, jej obiegu, recepcji i promocji, rozwija się dziś dynamicznie poza tradycyjnymi półkami księgarskimi, przenosząc się w świat portali i serwisów internetowych. Ich kształt i sposób zarządzania znacząco wpływają na to, co i jak jest czytane, oglądane, komentowane czy wreszcie kupowane. Za sprawą rozwoju świadomości na temat funkcjonowania Internetu i masowego dostępu do niego, spowodowanego szczególnym modelem kultury uczestnictwa, literatura zamieszkała w Sieci. Nowe „życie” literatury dynamizuja procesy wymiany treści, tekstów, opinii za pośrednictwem rozmaitych witryn takich, jak: strony, blogi, fora, grupy dyskusyjne, elektroniczne pisma i wreszcie - portale i wortale literackie.

Pierwsze oferują szeroki zakres funkcji związanych z publikacją tekstów, ich odbiorem czy nawiązywaniem relacji między twórcami i odbiorcami; budują wokół siebie zaangażowane społeczności, z których członkowie występuja poniekąd jako „architekci” danych aktualnego życia literackiego, ale także kulturowo zaangażowani obywatele sieciowej społeczności (Sieńko 2002: 113). Użytkownik portalu organizuje obieg informacji wewnątrz sieci, ale i wskazuje drogę do innych zasobów, ma wpływ na katalog odnośników do podstron serwisu i stron zewnętrznych, staje się współtwórcą szerokiego zakresu zasobów, takich jak: darmowa poczta, miejsce na własną stronę WWW, blog, infrastruktura czatów itp. Drugie mają niejako charakter specjalistyczny. Wortale, skupiając się na konkretnych zjawiskach, gatunkach, tematach, przeznaczone są dla węższej grupy odbiorców (zob. Pręgowski 2006: 417). Organizacja i zarządzanie informacjami w witrynach literackich opierają się na uniwersalnych zasadach architektury Sieci. Najważniejsze spośród nich to: rozbudowana i ustrukturalizowana baza danych, otwarta na efekty intermedialne, estetyczno-wizualna atrakcyjność układu treści, jako swoiście „elitarnego wszechświata” (Marecki 2002: 5) i wreszcie interaktywność, związana z ciagłą możliwością wymiany opinii, personalizacji zawartości portalu, promocji wizerunku użytkowników (Siwak 1998: 158), popularyzacji online wydarzeń literackich i kulturalnych oraz tworzenia przestrzeni interakcji grupowej.

Powtórzmy zatem: kultura w modelu 2.0 to świat zdemokratyzowanych i pozbawionych hierarchii porządków, świat „wolnego dostępu”, który rządzi się prawami cybernetycznej organizacji wiedzy i obiegu tekstów kultury. Śledzenie własności tego modelu kultury pokazuje drogę transformacji między estetyką „,starych” i „nowych” mediów, pozwala zaobserwować jak zmienia się dotychczasowy status pisarza, odbiorcy, krytyka i badacza kultury, uświadamia, jak pod wpływem nowoczesnych nośników zmieniają się 
formy i funkcje przekazów literackich, a za tym, jak tworzy się i na czym polega nowy, intermedialny paradygmat literatury i literackości (zob. Maryl 2016). Pokazuje wreszcie, jak technologiczne uwarunkowania komunikacji zmieniają samo pojęcie tekstu, stającego się tworem hybrydycznym, poddawanym moderacji i wciąż nasilającym się konwergencjom intermedialnym.

\section{Tekst w Sieci. Projekt komunikacji intermedialnej jako synergia tworzyw i dyscyplin}

Współczesny pejzaż płynnych przestrzeni tekstu i znaczenia, technologii informatycznych, nowych rynków zbytu i promocji kultury, komunikacyjnej współzależności nadawców i odbiorców pokazuje, że zasadnicza zmiana statusu tekstu i tekstowości wiąże się z różnicującymi się procesami konwergencji, zarówno mimetycznej, włączającej do przekazów tradycyjnych cechy form nowomedialnych, jak i konwergencji mimikrycznej, akcentującej zjawiska odwrotne (Jenkins 2007: 256-257).

Musimy pamiętać, że istota architektury informacji opiera się właśnie na dialogu systemów znakowych, związkach między cyberprzestrzenią a językiem, jego semantyką, kontekstowym stosowaniem kodów językowych i kulturowych, a więc na semiotyce i antropologii kultury, zwłaszcza kultury przekazów polimedialnych. Mówimy tu o takich wyzwaniach, jak elastyczne, trafne i kreatywne posługiwanie się językiem i właściwy sposób prezentacji treści, jakie zawiera komunikat słowny. Sprawności te winny iść w parze z wizualną i audiowizualną organizacją pejzażu danych, gdyż transsemiotyczny kod porządkowania informacji, jej typologizowania i wizualizowania okazuje się kluczową racją w skonstruowaniu systemów nawigacji łączących wydzielone kategorie informacji.

Czy zatem, w myśl prognoz Lva Manovicha, dzisiejsze elektroniczne praktyki tekstotwórcze prowadzą do powstawania artefaktów kultury oprogramowania (software culture; Manovich 2008: 17)? Wydaje się to zbyt daleko idącym przypuszczeniem, zważywszy na fakt, że pojęcie kodu, logosu komputera jest, w przeciwieństwie do kodów języka, przejściowym, zmiennym tworzywem zrozumiałym wewnątrz własnej struktury.

Przyznać musimy jednak, że w czasach digitalnej transformacji organizacja i tworzony przez architektów informacji nowy język informatycznej mapy znaczeń, wyznacza nowe kierunki kultury multimediów, cyberliteratury, praktyk liberackich i słowno-performatywnych, liternetu, badania tekstowych partytur hipertekstualności, poezji eksperymentów nowomedialnych. Potwierdzeniem tej relacji jest funkcjonalne zastosowanie takich cech tekstu medialnego jak: cytacyjność, kliszowość, ikoniczność, heterogeniczność znakowa, eliptyczność, kolażowość, polisensoryczność, hipertekstowość, filmowy symultanizm, poetyka wideoklipu, symulakryczność, interaktywność, modułowość i wariacyjność.

Nie jest odkryciem, że nowe technologie przesuwają granice tekstu w stronę paradygmatu wizualnego, w stronę figuralnej zmysłowości epoki ekranów oraz — jak rzecz ujmuje Karen Wenz — „wirtualnej sieci śladów”. Wyjaśniając istotę tego sformułowania, badaczka struktur tekstowych udowadnia, że:

wirtualna obecność wielu głosów [tworzy] multimedialną przestrzeń sprawiająca, że tekst powstaje jako sieć śladów, które w nieskończoność odsyłają do innych śladów. Sam tekst przekracza tym samym granice, które są mu przypisane. [Nowy status tekstu określają zasady takie jak]: przyspieszenie, usieciowienie, fragmentacja i montaż, bliskość, wizualizacja. (Wenz 2008: 108) 
Idąc tropem poetyk interaktywnych, architekci informacji projektują teksty w działaniu. Tekst performatywny „działa” we współpracy człowieka i maszyny, jest zbiorem asocjacji, ma charakter przestrzenny, dynamiczny, mobilny, staje się wielotorowym zapisem naturalnej pracy umysłu (Pisarski, 2002: 127-150). Przypomnijmy, że cybertekst w ujęciu medioznawczym postrzegany był jako:

artystyczna baza danych uwolniona od norm narracyjnej syntagmy, zbiór leksji do konstruowania swobodnych połączeń, których konceptualną zasadę określa odbiorca komunikatu.(...); nielinearna i niesekwencyjna organizacja danych jest tekstem rozbitym na poszczególne leksje i połączonym linkami. (Marecki, 2002: 10)

Co więcej, czytelnik jako reprezentant społeczeństwa sieciowego — zdaniem Derricka de Kerckhove'a - modeluje atrybuty swego umysłu, dostosowując je do obiegu i dystrybucji informacji w Sieci. Pozwala to uznać hipertekst za „dziecko hiperaktywnego umysłu” oraz wynik „,upadku umysłu linearnego”. Teoretyk mediów uznaje, że „zasada hipertekstu pozwala traktować Sieć jako swego rodzaju rozszerzenie zawartości umysłu. Hipertekst przekształca pamięć jednego człowieka w pamięć wszystkich ludzi, tworząc z Sieci pierwszą pamięć ogólnoświatową" (de Kerckhove 2001: 97-98). Interaktywny projekt tekstu poszerza pole hipertekstowej gry, której obszar opanowały media elektroniczne i prawa nimi rządzące. Jay David Bolter stwierdza wręcz, że:

(...) dziś hipertekst to zwykle hipermedia. (...) uczestnicza [one] w procesie remediacji, w procesie reakcji piśmienności na wizualne techniki fotografii, kina i telewizji (...), analogowych i cyfrowych mediów wizualnych (...). Zmieniają się proporcje między tekstem a obrazem, zmienia się kształt samej piśmienności, [prowadząc] do łączenia mediów wizualnych z drukiem. (...) Projektanci hipermediów wykorzystują obrazy, a także dźwięki, po to, by dawać doznania prawdziwsze albo bardziej bezpośrednie, niż dawałyby tylko słowa (...). Hipermedia można uznać za swego rodzaju pismo obrazkowe, które przekształca cechy zarówno tradycyjnego pisma obrazkowego, jak i pisma fonetycznego (...). Hipermedia przekształcaja pismo fonetyczne, by od nowa podkreślić status elementów obrazowych [wtopionych] w tekst interaktywny. Graficzny interfejs użytkownika sam stanowi taki tekst. Ponieważ obrazy i tekst słowny należą w interfejsie do jednej przestrzeni, obrazy moga przekraczać granice i stawać się symbolami tekstu. (Bolter 2008: 119-141)

Zdaniem Karen Wenz hipertekst jest kolażem pozbawionym materialnej jedności. Rządzi nim kombinatoryka, zróżnicowana gęstość jednostek i więzów, symulacyjna ulotność znaków:

Przestrzeń pisania już od dawna nie jest pamięcia [papieru], ale ekranem świetlnym, na którym można manipulować wszystkimi danymi, nie pozostawiając śladów. Każdy obraz tekstu, każdy stan tekstu jest równie pierwotny. Hierarchizacje pisma lub mediów tracą w hipertekście swój autorytet. (Wenz 2008: 109)

W obrębie kultury nowych mediów redefinicji podlega także Gennette'owska kategoria paratekstu, stającego się bądź rekomendacją odsyłającą do innych tekstów, bądź swoistym „prefabrykatem kultury”, bądź też „ramą dyskursywną dla tekstu bazowego” (Pietrzykowski 2011: 17). Wskazana modulacja znaczeniowa pozwala znakomicie wydobyć istotę prawidłowość, zgodnie z którą „przedrostek para- wskazuje na efemeryczność i uzależnienie tekstu od pewnej materii wyjściowej. Im »gorętszy« jest tekst (...), tym większy jest 
kwantytatywny wymiar tekstów okalających go" (Pietrzykowski 2011: 18). Zasada ta odnosi się także do sposobu istnienia i oddziaływania komunikatu w dobrze zaprojektowanej witrynie internetowej, czy sugestywnie zbudowanej infografice reklamowej. Przemawia to po raz kolejny za tym, że kompetencje architekta informacji stają się komplementarne wobec umiejętności twórcy tekstów interaktywnych i odwrotnie.

Idąc dalej, za składowe badawczego i operacyjnego instrumentarium architektury informacji uznać wypada z całą pewności zagadnienia z pogranicza współczesnej tekstualności, tekstologii i edytorstwa cyfrowego, dla których z kolei kluczowe stają się kwestie głównych wyróżników architektury publikacji i architektury tekstu, a zwłaszcza jego intermedialnej funkcjonalności komunikacyjnej (tekst polimedialny, infografika, słowa kluczowe, pozycjonowanie, kontekstowe generowanie znaczeń, budowanie sieci semantycznych, nawigacja kontekstowa, metadane, słownik kontrolowany). Z kolei, wskazane przez badaczy cechy, takie jak: redundancja (rozumiana jako nadmiar znaczeń i kontekstów), recyklingowość form, strategia voyeurystyczna, teatralizacja komunikacji, performatywność, rytualność happeningowa, translokacja i osmoza znaczenia, progresywizm, nawigacyjność, labiryntowość, nomadyczny status podmiotu i tekstu, konceptualność, kolaż (mozaika) kontekstów, zdają się określać cały katalog praktyk wywiedzionych czy też inspirowanych przez wielodziedzinową architekturę tekstu.

Winniśmy zatem do słownika pojęć architektury informacji włączyć takie terminy, a za nimi obszary badań nowoczesnej humanistyki, jak: cybertekstualność, interfejs kulturowy, hipertekstualność, palimpsest literacki i kulturowy, ergodyczność literatury (interaktywny tekst literacki, technotekst), interakcja: człowiek-maszyna, tekst wizualny, audiowizualny hipermedialny, performatywny, liternet, liberatura. Przemawia to za tym, że architektura informacji, wciąż dookreślając swój obszar praktyk, otwiera się na nowoczesne interdyscyplinarne terytorium, staje się instrumentem społecznych zmian, przestrzenią praktycznych relacji i translacji, rodzajem praktycznie stosowanej komparatystyki intermedialnej, przeniesionej w sferę informatycznych narzędzi zarządzania wiedzą i informacją.

\section{Homo consumens jako generator znaczeń kulturowych}

Skomplikowane narzędzia architektury informacji nie pozostają bez wpływu na przestrzeń praktyk kulturowych, w tym praktyk znaczeniotwórczych. Dają możliwość szybkiego i skutecznego dotarcia do informacji, pokazując jak skutecznie wykorzystywać ją w celach biznesowych, marketingowych, promocyjnych czy kulturowych. Słynny amerykański specjalista od marketingu, odpowiedzialny między innymi za sukcesy firmy Apple — Guy Kawasaki, pokazując nośność projektowania nowych obszarów nazewnictwa sieciowego oraz kształtowania środowisk informacyjnych, stwierdził: ,Jeśli stworzysz znaczenie, stworzysz też pieniądze". Teza ta ma pokazać, że kreatywna postawa menedżera informacji daje przewagę nad konkurencja, dynamizuje rynek, jest elementem biznesu w świecie komunikacji cyfrowej. Ekspansywny dyskurs moderatorów kultury e-komunikacji nie boi się mówić wprost: „jeżeli nie uczysz się szybciej niż konkurencja, w końcu przegrasz”. Nawet jeśli architekt informacji działa metodologicznie, z zastosowaniem specjalistycznych metod i narzędzi organizacji treści i zarządzania nimi, nie ujawnia koncepcji, wedle której tworzy swoją budowlę. Jego celem jest spowodować, by była najpiękniejsza i najskuteczniejsza w swym oddziaływaniu na jej potencjalnych użytkowników. Kluczowym narzędziem architektury informacji zorientowanej na działania promocyjne jest tzw. posycjonowanie, czyli 
najprościej mówiąc, dążenie do stanu, kiedy ważne dla nas treści (strony WWW, blogi) pojawią się w oknie przeglądarki jako pierwsze, te najbardziej zwracające uwagę internautów. Webmaster pozycjonując, tworzy swoje „tajne” zaplecze, czyli dużą ilość stron internetowych o roboczym charakterze połączonych tematycznie, tylko po to, by z nich odsyłać linkami do strony głównej, czyli tej właściwie promowanej. Projektuje tym samym przestrzeń „życzliwych” pejzaży intermedialnych, które generując sieć znaczeń, „pracuja” niejako na wyeksponowanie i wylansowanie tego, które jest znaczeniem (treścią, informacja) macierzysta, kluczowa.

Informacyjna topologia sieci jako sposób organizacji informacji i ich przepływu determinuje niejako funkcjonalną strukturę połączeń środowiskowych, w których dowolne jednostki oddzielone są od siebie mała liczbą pośredników o różnym stopniu powiązania, między którymi dochodzi do nieustannej wymiany informacji, poglądów, zasobów biznesowych. Zjawisko określane jako networking, to kolejny dowód sieciowej demokracji, czyniącej wszystkich równymi i jednakowo ważnymi (jako źródła wiedzy i wymiany danych); demokracji pozwalającej także przekraczać homogeniczne granice środowisk (Szpunar 2011: 6-7).

Nie od dziś procesy wyboru treści, traktowanych na równi z produktami i towarami, coraz częściej noszą znamiona social shopping; są uzależnione od opinii zaczerpniętych z serwisów społecznościowych. Zjawisku temu towarzyszy pojawienie się, charakterystycznych dla kultury Web 2.0, serwisów typu mashup, czyli aplikacji wykorzystującej istniejące już programy lub bazy danych udostępniane publicznie, których kompilacja dostarcza nowego doświadczenia i nowych możliwości popularyzacji danych (Tyszkowska 2015: 23-24).

Coraz częściej komentowanymi przez znawców komunikacji internetowej są praktyki społecznego indeksowania (tagowania) wybranych treści, zwane przez Thomasa Vander Vala folksonomia, czyli (w dosłownym tłumaczeniu) zarządzaniem klasyfikacją treści przez ludzi, czy też „ludowe” zarządzanie klasyfikacją (zob. Stępień 2010). Chodzi o praktykę kategoryzowania treści za pomocą wybranych słów lub fraz kluczowych z myślą o ich odbiorcach, użytkownikach, konsumentach. Pojęciowym dopełnieniem tego zjawiska sa terminy: tag (znacznik), Sié́ 2.0 (Web 2.0) oraz social media. Tagi funkcjonuja jak swoiste „klucze do chaosu” (Zaremba 2011: 113). Umożliwiaja samodzielne etykietowanie publikacji internetowych w celu ułatwienia do nich dostępu i/lub wskazania istoty informacji dla innych użytkowników Sieci. „Chmurę tagów” — graficzno-tekstowe przedstawienie mapy strony internetowej tworzą kolejno: frazy — linki — fotografie. O hierarchiczności tagów decydują zaś takie elementy jak: „wewnętrzne algorytmy danego serwisu analizujące częstotliwość użycia i kliknięć tagu, preferencje administratora dotyczące pozycjonowania tagu oraz indywidualne ustalenia społeczności danej witryny" (Zaremba 2011: 114).

Jakie korzyści dla e-marketingu wynikaja z tego zjawiska? Tagujący objawiaja swoje zainteresowania, doświadczenie i wiedzę; stają się nieświadomymi współtwórcami kapitału informacji, jaka staje się przedmiotem masowego obiegu. Efekty ich pracy są niejako żywym materiałem dynamicznego procesu przepływu danych, a pozyskany kapitał danych wykorzystaniem kolektywnej inteligencji. Badacze zjawiska folksonomii, stanowiącej jedną z kluczowych cech modeli Sieci 2.0, wskazują na „ryzyko manipulowania przekazem”, na problem „wymuszonej popularności, czyli sytuacji, gdy ważność tagu nie wynika bezpośrednio z częstotliwości zastosowań, lecz jest wtórna wobec preferowanej pozycji w chmurze" (Zaremba 2011: 114). 
Czy nowy paradygmat interaktywnego hierarchizowania treści można uznać za świadomy projekt architektoniczny? Jeśli tak, to przy założeniu, że spodziewana konstrukcja nie ma planu, jest ze swej zasady alinearna, mobilna i oparta na regule przypadku. Tu architektem staje się każdy, a właściwie wszyscy. Pamiętać jednak musimy, że owa zmasowana i dość anonimowa kreacja staje się udziałem nie człowieka, ale „ludowej” masy sterowanej przez technologicznie zaprojektowany system, którego pojedynczy człowiek jest w gruncie rzeczy tylko narzędziem.

\section{Po stronie wartości. Humanista wobec reżimu technokracji}

Czy humanizowanie świata technologii powinno być swoistym nakazem kulturowym, a jeśli, to jak ów proces winien przebiegać? Z cała pewnością rzec można, że misją architektury informacji jest praktyka humanistyczna realizowana tak, by porządkowanie nadmiaru informacji nie stało się sztuką samą w sobie i kolejnym rodzajem nadorganizacji formalnej „szyfrującej” rzeczywistość. Rzecz raczej w tym, by owa zasada porządkowania była realnie bliska człowiekowi, w różnym przecież stopniu sympatyzującemu z kulturą i strukturą Sieci. Jednym z humanistycznych wyzwań architektury informacji jest dość oczywisty postulat: ułatwianie życia człowiekowi, funkcjonującemu na co dzień w nadmiarze różnych komunikatów. Efektywne wykorzystywanie nowoczesnych technologii informatycznych ma przecież służyć zaspokajaniu codziennych potrzeb człowieka, czyniąc go podmiotem oraz kreatorem nowych znaczeń społecznych i kulturowych. Humanista w świecie wysoko rozwiniętych technologii, jako podmiot kreujący nowe, praktyczne narzędzia służące ekonomii i ekologii wiedzy rejestrowanej cyfrowo, ale także informacji o charakterze niewirtualnym, jest odpowiedzialny za to, by znak, język i tekst (słowny, ikoniczny, audiowizualny) umieszczony w Sieci spełniał swą funkcję komunikacyjną, był czytelny i jasny. By generował nowe treści zależnie od kontekstu i zastosowania. By realizować ten cel, niezbędna jest wiedza o znakach kulturowych oraz kreatywna umiejętność ich użycia. Pamiętać należy także, że odpowiedzialność projektanta informacji to także sfera, tak problematycznej dziś etyki Internetu. Stąd istotnym humanistycznym postulatem w pracy architekta informacji jest szczególna dbałość o to, by zarządzanie informacją i sposób jej użycia nie był narzędziem manipulacji marketingowej, ale by chronił prawa wolności wyboru i kultury obiegu informacji, zgodnie ze standardami etyki komunikacji. Tu sfera wartości może motywować efektywność, gdy cele biznesowe równoważą potrzeby użytkowników i odwrotnie. Podstawą jest więc efektywne zarządzanie oraz jasna polityka i procedury działania.

Architekt informacji wie, że znaczenie generuje wartość i samo nabiera wartości rynkowej. Stąd inteligentna organizacja słów, haseł, obrazów i znaków zorientowana na skuteczność nie może wyprzedzać ich samych. Tak jak doskonała budowla z nich ułożona nie może być li tylko idealnym tworem samospełniającej się idei. Naukowy paradygmat omawianej dyscypliny w swym dalszym rozwoju objąć musi z pewnością obszar zagadnień dotyczących relacji między cyberprzestrzenią a modelami/konstruktami podmiotowości i tożsamości ponowoczesnej, włączając się w dyskusję nad problemami transhumanizmu i posthumanizmu, jako swoistymi wytworami kultury Sieci. Tam bowiem, gdzie podmiot i jego czysto humanistyczne racje pozostają w cieniu cybernetycznych praktyk, a mediologia służy konsumpcyjnemu ubezwłasnowolnieniu, rodzi się reżim technokultury, współczesny rodzaj totalitaryzmu, o którym w tonie pesymizmu pisali z pasją Jean Baudrillard, Paul Virilio, Slavoy Žižek i wielu innych. 
Udowadniali oni po wielokroć, że wirtualne światy hiperrzeczywistości wprowadzają współczesnego człowieka ekranów w stan, w którym doświadczenia medialności i cielesności wydają się komplementarne. Ekran staje się ciałem, a ciało ekranem. Samo wyjście poza cielesną realność polega bowiem na zawieszeniu rzeczywistości, pogrążeniu się w wirtualnej przestrzeni ekranowego fantazmatu, w digitalnym oceanie interfejsów. Jak trafnie zauważa Piotr Celiński:

pokartezjański pochód unieważniania cielesności, sprawia, że ciało ludzkie ulega technologizacji i cyborgizacji w dwojaki sposób: staje się sprawnym, odsublimowanym urządzeniem lub separuje rozum i duchowość od „balastu” cielesności”. (Celiński 2010: 142)

Ta dezintegracja wydaje się przywoływać istotę freudowskiego konfliktu tożsamości ludzkiej, wskazując zarazem na powszechność „ciała post-ludzkiego” (Bodzioch-Bryła 2006) oraz na zastapienie wyobraźni i zmysłowej wizualności zjawiskiem określanym przez Waltera Benjamina i Marshalla McLuhana „radykalną taktylnością, czyli ultracielesna „przyległością oka i obrazu" (Loska 2001: 144-148). W ten sposób ciało uwikłane w hipertrofię medialności staje się obszarem technologicznego eksperymentu, genetycznej i fizjologicznej ekspansji digitalnej. Jako narzędzie resetowania i tuningowania przybiera postać obrazu samego siebie, formy karykaturalnego image'u i symulacji. Rozbicie integralności, suwerenności i samoistności ciała, a przez to tożsamości antropologicznej — jak dowodzą badacze cyberkultury — traktowane jest jako wyzwanie przeciw mediatyzacji, jak u Wolfganga Welcha (1998: 186-187) lub jako nieuchronne zagrożenie, jak widzi to Paul Virilio (zob. Virilio 2006).

Nie wolno nam zatem pomijać faktu, że nowa kultura informacji staje się generatorem kulturowego multiwersum, obejmującego wielość światów doświadczanych jednocześnie, ale pozbawionych korelacji, płaszczyzny odniesienia czy reprezentacji. Benjamin Barber mówi wręcz, że mamy do czynienia z mediologiczną transgresją która:

przemienia życie w konsumowanie, konsumowanie w znaczenie, znaczenie $\mathrm{w}$ fantazję, fantazję w rzeczywistość, tę zaś z kolei w rzeczywistość wirtualna, a zamykając krag z powrotem, przetwarza rzeczywistość na prawdziwe życie. (...) W gruncie rzeczy zamazują się wszelkie granice.

(Barber 131-132)

\begin{abstract}
$* * *$
Przedstawione tu rozważania, choć nie wyczerpują tematu, pozostawiając wiele niedomkniętych wątków, pozwalają stwierdzić, że omawiana architektura informacji (jako pojęcie składowe architektury Internetu) wpisuje się trwale w katalog pojęć postindustrialnej rzeczywistości społeczeństw informacyjnych. Włączając się w proces transformacji kulturowych dokonujacy się w mikro — i makroskali, zarówno w sferze socjologicznej, instytucjonalnej, jak i formalno-estetycznej, zmienia status życia literackiego i kulturalnego oraz status instytucji mu służących. Wreszcie rewiduje samo rozumienie humanistyki, a także określa dla nauki oraz dystrybucji wiedzy nowe wzorce kondycji percepcyjnych, poznawczych, metodologicznych. Jako „dziecko” dwudziestopierwszowiecznej komunikologii i informatologii, architektura informacji na poziomie metanaukowym współtworzy współczesne oblicze nie tylko antropologii Internetu, ale antropologii i historii kultury
\end{abstract}


w ogóle. Rozwija się jako dziedzina o coraz szerszym spektrum zainteresowań, wśród których niebagatelną rolę odgrywają zagadnienia kształtujące oblicze współczesnej humanistyki. Będziemy zatem bronić stanowiska, że jej ewolucja winna uwzględniać nie tylko najnowsze parametry technokultury, ale przede wszystkim być skierowana na „humanizację" podmiotowego statusu człowieka ery informacyjnej. Dziedzina ta ma zatem sens i może należycie spełniać swe funkcje wtedy, gdy odnajduje właściwe proporcje między siecią znaczeń a siecią konsumpcyjnych interesów i zysków, siecią liczb, danych i wskaźników; gdy mówi o człowieku i jest dla człowieka, bo w przeciwnym razie przeczy sama sobie, bardziej szkodzi idei użyteczności, niż ją upowszechnia.

\section{Bibliografia}

Babik Wiesław (2016), Środowisko informacyjne çłowieka [w:] Nauka o informacji. Nauka-Dydaktyka-Praktyka, red. W. Babik, Wydawnictwo SBP, Warszawa.

Barber Benjamin (2013), Dįihad kontra McŚwiat. Jak nasz świat dzieli się, a zarazem jednoczy i co to oznacza dla demokracji, przeł. H. Jankowska, Warszawskie Wydawnictwo Literackie MUZA, Warszawa.

Bodzioch-Bryła Bogusława (2006), Ku ciału post-ludzkiemu. Polska poezja po 1989 roku wobec nowych mediów i nowej rzecayywistości, Wydawnictwo WAM, Kraków.

Bolter Jay David (2008), Eksplozja obrazón, przeł. J. Mach [w:] Ekrany piśmienności: o prayjemnościach tekstu w epoce nowych mediów, red. nauk. A. Gwóźdź, WAiP, Warszawa.

Bomba Radosław (2013), Narzedzia cyfrowe jako wyznacznik nowego paradygmatu badań humanistycznych [w:] Zwrot cyfrowy w humanistyce, red. A. Radomski, R. Bomba, E-naukowiec, Lublin.

Bonecki Mateusz (2012), Sensemaking — wiedza i kultura organizacji w świetle humanistyki zintegrowanej, „Filo-Sofija”, nr 18.

Celiński Piotr (2010), Interfejsy. Cyfrowe technologie w komunikowaniu, Wydawnictwo Uniwersytetu Wrocławskiego, Wrocław.

Cisek Sabina (2002), Filozoficzne aspekty informacji naukowej, Wydawnictwo UJ, Kraków.

- (2008), Nauka o informacji na swiecie w XXI wieku: badania metanankowe, 2008 UNSPECIFIED, (n.p.), http://eprints.rclis.org/11098/1/Cisek_in_na_swiecie_eng.pdf [dostęp: 22 lutego 2017].

Gmiterek Grzegorz (2016), Od Web 1.0 do Web 3.0. Interaktywnośc a ewolucja sieci [w:] Nanka o informacji. Nauka-Dydaktyka-Prak.tyka, red. W. Babik, Wydawnictwo SBP, Warszawa. 
Gray Jim (2001), Przedmowa [w:] Abiteboul Serge, Buneman Peter, Suciu Dan, Dane w sieci $W W W$. Od relacji do modelu semistrukturalnego i XML, przeł. B. Bragoszewski, P. Pędzik, S. Dzieniszewski, Mikom, Warszawa.

Grygrowski Dariusz (2001), Dokumenty nieksiagkowe w bibliotece, Wydawnictwo SBP, Warszawa. Jenkins Henry (2007), Kultura konwergencji. Zderzenie starych i nowych mediów, przeł. M. Bernatowicz, M. Filiciak, WAiP, Warszawa.

Jonak Lukasz, Mazurek Pawel, Tarkowski Alek (2006), Wstep [w:] Re-internet - społeczne aspekty medium. Polskie konteksty i interpretacje, WAiP, Warszawa.

Kerckhove de Derrick (2001), Inteligencja otwarta. Narodziny społecæeństwa sieciowego, przeł. A. Hildebrandt, R. Glegoła, Mikom, Warszawa-Toronto.

Kmita Andrzej (2002), Wywiad (rozmawia Andrzej Radomski), „Kultura i Historia”, nr 3/2002, http://www.kulturaihistoria.umcs.lublin.pl/archives/108 [dostęp: 20 lutego 2017]. Krzysztofek Kazimierz (2010), Hiperpieniqdz w hiperspoleczeństwie [w:] Wirtual — czy nowy wspanialy śmiat?, red. K. Korab, Wydawnictwo Naukowe Scholar, Warszawa.

Kulczycki Emanuel (2011), Teoretyzowanie komunikacji, Wydawnictwo Naukowe IF UAM, Poznań. Lesk Michael (1997), Cyfrowe ksiażki, „Świat Nauki”, nr 5.

Loska Krzysztof (2001), Driedzictwo McLubana - międry nowoczesnościa a ponowoczesnościa, Rabid, Kraków.

Marecki Piotr (2002), Liternet [w:] Liternet: Literatura i internet, red. P. Marecki, Rabid, Kraków. Maryl Maciej (2016), Życie literackie w sieci. Pisarze, instytucje i odbiorcy wobec przemian technologicznych, IBL PAN, Warszawa.

Pieczonka Marek (2007), Digitalizacja zbiorów i ich wykorzystanie w pracach badawczych bibliologa [w:] Bibliologia. Problemy badawcze nauk bumanistycznych, red. D Kuźmina, Wydawnictwo Stowarzyszenia Bibliotekarzy Polskich, Warszawa.

Pietrzykowski Adam (2011), Open Source jako kult(ura) paratekstu, „Media - Kultura - Społeczeństwo”, nr 6.

Pisarski Mariusz (2002), Powieś́ jako zwierciadto umystu. Szkice do poetyki bipertekstu na podstawie klasyki gatunku: afternoon a story, Patchwork Girl, A Furtcher Xanadu [w:] Liternet. Literatura i internet, red. P. Marecki, Rabid, Kraków.

Powszechna Encyklopedia Filozofi, t. 4. (2003), red. A. Maryniarczyk, Polskie Towarzystwo św. Tomasza z Akwinu, Lublin, hasło: humanistyka, http://www.ptta.pl/pef/pdf/h/Humanistyka.pdf [dostęp: 17 lutego 2017].

Pręgowski Michał (2006), Międžy stowami. O wieloznaczności terminologii internetowej [w:] Re: internet - spotecrne aspekty medium. Polskie konteksty i interpretacje, red. nauk. L. Jonak i in., WAiP, Warszawa.

Rosenfeld Louis, Morville Peter (2003), Architektura informacji w serwisach internetowych, przeł. K. Masłowski, T. Jarzębowski, HELION, Warszawa.

Sieńko Marcin (2002), Człowiek w pajecsynie. Internet jako zjamisko kulturowe, Oficyna Wydawnicza ATUT, Wrocław.

Siwak Wojciech (1998), Hipertekstualna podróżprzez wirtualne światy [w:] Intermedialność w kulturze końca XX wieku, red. A. Gwóźdź, S. Krzemień-Ojak, Trans Humana, Białystok.

Skórka Stanisław (2002), Architektura informacji. Nowy kierunek rozwoju informacji nankowej, „EBIB Elektroniczny Biuletyn Informacyjny Bibliotekarzy” — Informacja biznesowa. Badania, teorie, wiæjje, Nr 11 (40) grudzień, http://www.ebib.pl/2002/40/skorka.php [dostęp: 20 lutego 2017]. 
- (2016), Architektura informacji [w:] Nauka o informacji. Nauka-Dydaktyka-Praktyka, red. W. Babik, Wydawnictwo SBP, Warszawa.

Stępień Kamil (2010), Folksonomie, çyli społecz̧nościowe opisywanie treści: poradnik, Wydawnictwo SBP, Warszawa.

Szpunar Magdalena (2011), Internet — nowe modele komunikacyjne çy powielanie schematów?, „Media - Kultura — Społeczeństwo", nr 6.

Tyszkowska Marta (2015), Jak korzystać z. Web 2.0 w każdej bibliotece?, Wydawnictwo SBP, Warszawa.

Virilio Paul (2006), Bomba informacyjna, przeł. S. Królak, Wydawnictwo Sic!, Warszawa.

Welch Wolfgang (1998), Sztuczne raje? Rozważania o swiecie mediów elektronicznych oraz o innych swiatach, przel. J. Gilewicz [w:] Problemy ponowoczesnej pluralizacji kultury. Wokót koncepcji Wolfganga Welcha, cz. I., red. A. Zeidler-Janiszewska, Wydawnictwo Fundacji Humaniora, Poznań.

Wendland Michał (2014), Filozoficzne i metodologiczne podstany historii komunikacï, Wydawnictwo Naukowe UAM, Poznań.

Wenz Karen (2008), Tekst w dobie jego reprodukcji elektronicznej, przeł. K. Krzemieniowa [w:] Ekrany pismienności: o prayjemnościach tekstu w epoce nowych mediów, red. nauk. A. Gwóźdź, WAiP, Warszawa.

Zamiara Krystyna (2002), Humanistyka zintegrowana. Idea i sposoby jej realizacji [w:] Drogi i ścieżki filozofii $i$ kultury, red. J. Kmita, J. Sójka, A. Zeidler-Janiszewska, Wydawnictwo Fundacji Humaniora, Poznań.

Zaremba Maciej (2011), Odpowiedni dać rzeczy... tag. Folksonomia jako uniwersalny model klasyfikacii treści w Internecie, „Media i Społeczeństwo”, nr 1. 